\title{
Türkiye'de Beşeri Sermayenin Ekonomik Büyüme Üzerindeki Etkisi: Gecikmesi Dağıtılmış Otoregresif Yaklaşımı
}

\author{
Zeki YILMAZ*, Pınar ÖZER***, Feride Gülsüm GÜMÜŞSOY**** \\ ÖZ
}

Bu çalışmada Türkiye için 1978 - 2014 arası yıllık verileri kullanılarak, beşeri sermayenin ekonomik büyüme üzerindeki etkisinin tahmin edilmesi amaçlanmıştır. Çalışmada değişkenler arasındaki uzun dönemli ilişkilerin varlığı Gecikmesi Dağıtılmış Otoregresif Sınır Testi yaklaşımı ile araştırılmıştır. Ekonometrik analizler sonucunda beşeri sermaye ve ekonomik büyüme arasında uzun dönemli bir ilişkinin varlığı tespit edilmiş olup uzun dönemde beşeri sermayenin ekonomik büyümeyi pozitif etkilediği sonucuna varılmıştır.

Anahtar Kelimeler: Beşeri Sermaye, Ekonomik Büyüme, Eşbütünleşme Analizi, Gecikmesi Dağıtılmış Otoregresif

JEL Sinıflandirması: O15, O40

\section{The Impact of Human Capital on Economic Growth in Turkey: Autoregressive Distributed Lag Approach}

\begin{abstract}
In this study the impact of human capital on economic growth for Turkey was aimed to estimate using annual data from 1978 to 2014. Long run relationship between variables in the study was investigated by the Autoregressive Distributed Lag Boundary Test approach. As a result of the econometric analysis, existence of long-run relationship between human capital and economic growth has been found and it is concluded that human capital has positively influenced economic growth in the long run.
\end{abstract}

Keywords: Human Capital, Economic Growth, Cointegration Analysis, Autoregressive Distributed Lag

JEL Classification: O15, O40

Dr. Öğr. Üyesi, Dumlupınar Üniversitesi, İktisadi ve İdari Bilimler Fakültesi, İktisat Bölümü, zeki.yilmaz@dpu.edu.tr, ORCID: 0000-0001-7056-2242

** Araş. Gör, Dumlupınar Üniversitesi, İktisadi ve İdari Bilimler Fakültesi, İktisat Bölümü, pinar.ozer@dpu.edu.tr, ORCID: 0000-0001-8109-9038

*** Doktora Öğrencisi, feride.gumussoy@ogr.dpu.edu.tr, ORCID: 0000-0002-0771-2356 


\section{GİRIŞ}

Küreselleşme, bilgi temelli ekonomi ve teknolojik ilerleme gibi son zamanlardaki gelişmeler, birçok ülke ve kuruluşu rekabet üstünlüğünü korumak üzere bir takım yeni yollar aramaya teşvik etmiştir. Bu doğrultuda rekabet üstünlüğünü korumanın büyük ölçüde daha yüksek beceriye sahip insanlar ile mümkün olabileceği fikri hâkim olmuş ve akabinde beşeri sermaye ulusların zenginliğinin önemli bir faktörü olarak tanımlanmıştır.

Beşeri sermayenin ekonomik büyüme üzerindeki etkilerinin araştırılıp analiz edilmesi iktisatçıların ve politika yapıcıların uzun yıllardır üzerinde durdukları bir konudur. Klasik iktisatçılara göre işgücü verimliliği, işgücü ve fiziksel sermaye ile diğer faktörler (teknik ilerleme) arasındaki orana bağlı olan dışsal bir faktör olarak kabul edilmekle birlikte eğitimin potansiyel üretkenlik artışı üzerindeki olumlu etkisi hesaba katılmamıştır. Klasik iktisatçılardan üç önemli isim Fisher (1906), Marshall (1930) ve Smith (1776) insanları sermaye olarak görmelerine karşın eğitim alanındaki yatırımları ele alan analizlerini verimlilik hakkındaki tartışmalarına dâhil etmemişlerdir (Schultz, 1961: 2 - 3). Beşeri sermaye ve büyüme ilişkisine yönelik ilk teoriler 1960'ların başıyla birlikte ortaya çıkmış olup söz konusu ilişkiyi açıklayan çalışmalar ilk kez Mincer (1958), Schultz (1961) ve Becker (1962) tarafından gerçekleştirilmiştir. Söz konusu beşeri sermaye teorisyenlerine göre beşeri sermaye tıpkı fiziki sermaye gibi olup eğitim ve sağlı alanlarında yatırımların yapılması yoluyla bireyin verimliliğini ve çıktı miktarını arttırarak ekonomik büyümeye katkı sağlamaktadır.

1960'lardan sonra beşeri sermaye ve ekonomik büyüme ilişkisi hem ampirik hem de teorik olarak içsel büyüme teorisyenleri tarafından tekrardan ele alınarak beşeri sermaye bir üretim faktörü olarak modele dahil edilmiştir. Solow büyüme modelini genişleterek önemli katk1larda bulunan Arrow (1962), Romer (1986, 1990), Lucas (1988), Mankiw vd. (1992), Aghion ve Howitt (1992), Barro (2001)'ya göre beşeri sermaye potansiyel büyümenin önemli bir kaynağıdır. Yeni bir ürün üretmek için kullanılan beceri ve yetkinliklerin tümü iktisat alanında bilgi olarak tanımlanmakta ve insanlar tarafından elde edilen bu bilgi içsel büyüme literatüründe ise beşeri sermaye olarak adlandırılmaktadır. İnsanların yeteneklerinin, ekonominin yapısını ve gelişimini şekillendirdiğine inanılmaktadır. Bilgi birikimi sayesinde yeni fikirler ortaya çıkmakla beraber üretkenlik ve ürünlerin kalitesi de artmaktadır. Daha geniş anlamda, daha yüksek beşeri sermaye, girişimciliği ve yeniliği de teşvik ederek daha yüksek büyüme oranlarına neden olmaktadır (Dakhli ve De Clercq, 2004: 123).

Teorik literatür, beşeri sermayenin büyüme sürecine katkısının iki şekilde olabileceğini açılamaktadır. İlk olarak beşeri sermaye bir üretken faktör olarak doğrudan üretim sürecine katılabilir. Bu bağlamda, beşeri sermaye birikimi doğrudan çıktı artışını doğuracaktır. Bu durum, düzey etkisi olarak adlandırılmaktadır. İkinci olarak eğitim inovasyonu, yeni teknolojilerin yayılmasını ve benimsenmesini kolaylaştırdığ 1 için beşeri sermaye teknolojik gelişmeyi arttırmada katkıda bulunabilir. Böylelikle beşeri sermaye düzeyi üretkenlik artışını etkileyebilir. Söz konusu ikinci etki oran etkisi olarak adlandırılır (Freire Serén, 2001: 585 - 586). Özetle, teorik olarak beşeri sermayenin ekonomik büyüme ile pozitif ilişkili olduğu kabul edilmektedir.

Beşeri sermaye yatırımı iki şekilde sınıflandırılır: sağlık ve eğitim. Sağlığın ekonomik büyüme üzerinde doğrudan bir etkisi vardır. Bir ülke ekonomik olarak geliştikçe söz konusu ülkenin nüfusunun sağlık durumu iyileşecektir. Sağlıktaki bu iyileşme, insanların daha iyi bir yaşam sürdürdüklerinin doğrudan kanıtıdır. Başka bir deyişle, sağlık insanların kendileri için değer verdiği bir şeydir. Fakat sağlığın bir de üretkenlik tarafı vardır: Daha sağlıklı insanlar fiziksel olarak daha güçlü olup daha uzun süre ve de daha çok çalışabilir. Aynı zamanda daha sağlıklı düşünebilirler. Daha sağlıklı bir öğrenci ise çok daha fazla şeyi hızlı bir şekilde öğrenebilir. Bu nedenle sağlığın daha iyi olduğu ülkelerde gelir düzeyi artacaktır. Sağlık gibi eğitim formundaki beşeri sermaye de ekonomik büyüme üzerinde önemli bir rol oynamaktadır. Çünkü eğitimli insanlar, bedenlerinin yanında akıllarıyla da çalışırlar. Fakat gelişmiş ülkelerde 
bir kişinin maaşını belirleyen en önemli unsur fiziksel yetkinlikten ziyade daha çok entelektüel beceridir. $\mathrm{Bu}$ sebeple kişinin zihnini geliştiren yatırım başka bir ifadeyle eğitim beşeri sermayenin en önemli yatırımı haline gelmiştir (Weil, 2009: 155 - 161).

$\mathrm{Bu}$ çalışmanın temel amacı Türkiye'de 1978-2014 dönemi için beşeri sermayenin ekonomik büyüme üzerindeki etkisini ampirik olarak araştırmaktır. Türkiye'de beşeri sermayenin ekonomik büyüme üzerindeki etkisini modelleyip analiz etmeye odaklanan kapsamlı bir ampirik literatür olmasına karşı bu çalışma literatürde beşeri sermayeyi temsilen sıklıkla kullanılan değişkenler yerine ortalama okullaşma süresi (Barro ve Lee, 2013) ve eğitimin getiri oranına (Psacharopoulos, 1994) göre hesaplanan beşeri sermaye endeksi ekonometrik analize dahil edilerek beşeri sermaye ve ekonomik büyüme ilişkisi Türkiye için tahmin edilmektedir. Çalışmanın geri kalan kısmı aşağıda gösterildiği şekilde planlanmıştır. 2. Bölümde; beşeri sermaye ve ekonomik büyüme ilişkisi üzerine yapılan ampirik çalışmalar ortaya konulurken, 3 . Bölümde; analiz kısmında kullanılan veriler açıklanmakta ve aynı zamanda ekonometrik çerçeve ve metodoloji sunulmaktadır. 4. Bölümde tahmin sonuçları analiz edildikten sonra 5. Bölümde çalışma sonuçlandırılmıştır.

\section{AMPIRIKK LITERATÜR}

Ulusal ve uluslararası literatürde beşeri sermaye ve büyüme ilişkisi üzerinde yapılmış birçok ampirik çalışma mevcut olduğu için literatür taraması sadece Türkiye üzerine yapılmış çalışmalarla sınırlı tutulmuştur. Literatürde beşeri sermayenin büyüme üzerindeki etkisini araştıran çalışmalar üç şekilde karşımıza çıkmaktadır: (i) sağlık ve ekonomik büyüme ilişkisi, (ii) eğitim ve ekonomik büyüme ilişkisi, (iii) sağlık ve eğitimin ekonomik büyüme ile ilişkisi. Bu doğrultuda, literatürdeki bazı ekonometrik çalışmalar aşağıda Tablo 1'de sunulmaktadır.

Tablo 1: Türkiye Üzerine Seçili Ampirik Çalışmalar

\begin{tabular}{|c|c|c|c|c|}
\hline Kaynak & Dönem & Değişkenler & Yöntem & Bulgular \\
\hline Çoban (2004) & 1980-1997 & $\begin{array}{l}\text { Kişi başına düşen gayri } \\
\text { safi milli hâsıla (GSMH), } \\
\text { İlkokul okullaşma oranı } \\
\text { (ILK), Ortaokul okullaşma } \\
\text { oranı (ORTA), Lise } \\
\text { okullaşma oranı (LISE), } \\
\text { Yüksekokul okullaşma } \\
\text { oranı (YUKSEK), } \\
\text { kamunun yapmış olduğu } \\
\text { eğitim harcamalarının } \\
\text { toplam harcamalar } \\
\text { içerisindeki payı } \\
\text { (HARCAMA) }\end{array}$ & $\begin{array}{c}\text { Johansen } \\
\text { Eşbütünleşme Testi, } \\
\text { Granger Nedensellik } \\
\text { Testi }\end{array}$ & $\begin{array}{c}\text { Uzun dönem bir ilişki } \\
\text { vardır. } \\
\text { ILK } \rightarrow \text { GSMH, } \\
\text { GSMH } \rightarrow \text { LISE, } \\
\text { LISE } \rightarrow \text { YUKSEK, } \\
\text { HARCAMA } \rightarrow \text { LISE }\end{array}$ \\
\hline $\begin{array}{l}\text { Çakmak ve Gümüş } \\
\qquad(2005)\end{array}$ & 1960-2002 & $\begin{array}{l}\text { Beşeri sermaye endeksi } \\
\text { (yazar tarafından } \\
\text { oluşturulmuş), reel gayri } \\
\text { safi milli hâsıla (Y), reel } \\
\text { sabit sermaye yatırımları } \\
\text { (K), işgücü (L) }\end{array}$ & $\begin{array}{c}\text { Engle-Granger } \\
\text { Eşbütünleşme Testi, } \\
\text { Johansen } \\
\text { Eşbütünleşme Testi }\end{array}$ & $\begin{array}{c}\text { Fiziki ve beşeri } \\
\text { sermayenin büyüme } \\
\text { üzerindeki etkisi } \\
\text { pozitif fakat beşeri } \\
\text { sermayenin büyümeye } \\
\text { katkısı fiziki } \\
\text { sermayeye kıyasla } \\
\text { daha düşük. }\end{array}$ \\
\hline
\end{tabular}


Optimum Journal of Economics and Management Sciences, Vo1. 6, No. 1- http://dergipark.gov.tr/optimum/

Yllmaz, Özer and Gümüssoy - The Impact of Human Capital on Economic Growth in Turkey: Autoregressive Distributed Lag Approach

\begin{tabular}{|c|c|c|c|c|}
\hline $\begin{array}{l}\text { Serel ve Masatç1 } \\
\text { (2005) }\end{array}$ & $1950-2000$ & $\begin{array}{l}\text { Gayri safi milli hâsıla (Y), } \\
\text { orta ögrretime kayıtlı } \\
\text { öğrenci sayısı }(\mathrm{H}) \text {, sabit } \\
\text { sermaye yatırımları }(\mathrm{K}) \\
\text { toplam işgücü }\left(\mathrm{N}^{\mathrm{e}}\right)\end{array}$ & $\begin{array}{c}\text { Johansen Eşbütnleşme } \\
\text { Testi, Vektör Hata } \\
\text { Düzeltme Modeli, } \\
\text { Granger Nedensellik } \\
\text { Testi }\end{array}$ & $\begin{array}{l}\text { Uzun dönem ilişkisi } \\
\text { var. } \\
\qquad \begin{array}{l}\mathrm{Y} \rightarrow \mathrm{H}\end{array}\end{array}$ \\
\hline Afşar (2009) & $1963-2005$ & $\begin{array}{l}\text { Gayri safi milli hâsıla } \\
\text { (GSMH), eğitim yatımları } \\
\text { (EY) }\end{array}$ & $\begin{array}{c}\text { Johansen } \\
\text { Eşbütünleşme Testi, } \\
\text { Granger Nedensellik } \\
\text { Testi }\end{array}$ & $\begin{array}{l}\text { Uzun dönem ilişki } \\
\text { yoktur. } \\
\mathrm{EY} \rightarrow \mathrm{GSMH}\end{array}$ \\
\hline $\begin{array}{l}\text { Erdoğan ve Yıldırım } \\
\qquad(2009)\end{array}$ & $1983-2005$ & $\begin{array}{c}\text { Gayri safi yurtiçi hâsıla } \\
\text { (GSYIH), Toplam eğitim } \\
\text { harcamaları (EHT), } \\
\text { Eğitim harcamaları } \\
\text { içerisinde yatırımın payı } \\
\text { (EHY), İlköğretim } \\
\text { (ILKOO), ortaöğretim } \\
\text { (ORTAOO), meslek lisesi } \\
\text { (MESLEKOO), genel lise } \\
\text { (GLISEOO) öğrenci } \\
\text { öğretmen oran, ilkokul } \\
\text { (ILKOK), lise (LISEOK), } \\
\text { yüksek öğretim } \\
\text { (YUKSEKOK) okullaşma } \\
\text { oranları }\end{array}$ & ARDL & $\begin{array}{c}\text { Uzun dönemli bir } \\
\text { ilişki vardır. ILKOO, } \\
\text { ORTAOO, } \\
\text { MESLEKOO ve } \\
\text { GLISEOO, ILKOK, } \\
\text { EHT değişkenleri ile } \\
\text { GSYIH arasında } \\
\text { pozitif ilişki; LISEOK, } \\
\text { YUKSEKOK, EHY } \\
\text { ile GSYIH arasında } \\
\text { negatif ilişki vardır. }\end{array}$ \\
\hline Özsoy (2009) & $1923-2005$ & $\begin{array}{c}\text { Reel gayri safi yurtiçi } \\
\text { hâsıla (GSYİH), } \\
\text { ilköğretim } \\
\text { (İLK), ortaöğretim (ORT), } \\
\text { mesleki ve teknik eğitim } \\
\text { (MESL), } \\
\text { yükseköğretimdeki (YÜK) } \\
\text { öğrenci sayıları }\end{array}$ & $\begin{array}{c}\text { Johansen } \\
\text { Eşbütünleşme Testi, } \\
\text { Granger Nedensellik } \\
\text { Testi, Var Analizi, } \\
\text { Varyans Ayrıştırması }\end{array}$ & $\begin{array}{c}\text { Uzun dönemli ilişki } \\
\text { vardır. } \\
\text { İLK } \longleftrightarrow \text { GSYİH } \\
\text { GSYİH } \longrightarrow \text { ORT } \\
\text { MESL } \longrightarrow \text { GSYİH } \\
\text { YÜK } \longrightarrow \text { GSYİH } \\
\text { Ekonomik büyüme } \\
\text { eğitim arasında pozitif } \\
\text { ilişki vardır. } \\
\end{array}$ \\
\hline Zortuk vd. (2009) & $1970-2008$ & $\begin{array}{c}\text { Öğrenci başına eğitim } \\
\text { harcaması (ED), okula } \\
\text { kayıtlanma oranı (SR), } \\
\text { reel gayri safi yurtiçi } \\
\text { hasıla (GDP) }\end{array}$ & ARDL & $\begin{array}{l}\text { Kısa dönem katsayıları } \\
\text { negatif ve istatistiki } \\
\text { olarak anlamsız } \\
\text { bulunmuşken uzun } \\
\text { dönem katsayı } \\
\text { işaretleri pozitif ve } \\
\text { istatistiki olarak } \\
\text { anlamlıdır. } \\
\end{array}$ \\
\hline $\begin{array}{c}\text { Altıntaş ve Çetintaş } \\
\text { (2010) }\end{array}$ & $1970-2007$ & $\begin{array}{l}\text { Kişi başına gelir (RY), } \\
\text { İhracatın gelire oranı } \\
\text { (EXY), yüksek ögretim } \\
\text { kurumlarında diploma } \\
\text { alan toplam öğrenci sayısı } \\
\text { (HC), toplam sabit } \\
\text { sermaye birikiminin gelire } \\
\text { oranı (SSBY) }\end{array}$ & $\begin{array}{c}\text { Johansen-Juselius } \\
\text { Eşbütünleşme Testi, } \\
\text { Hata Düzeltme } \\
\text { Modeline Dayalı } \\
\text { Granger Nedensellik } \\
\text { Testi }\end{array}$ & $\begin{array}{c}\text { Uzun dönemde pozitif } \\
\text { ilişki var. } \\
\text { SSBY } \longrightarrow \text { EXY } \\
\text { SSBY } \longleftrightarrow H C \\
\text { EXY } \longleftrightarrow H C \\
\text { SSBY } \longleftrightarrow \text { RY } \\
\text { RY } \longrightarrow \text { HC } \\
\text { EXY } \rightarrow \text { RY }\end{array}$ \\
\hline
\end{tabular}




\begin{tabular}{|c|c|c|c|c|}
\hline Beşkaya vd. (2010) & $1923-2007$ & $\begin{array}{c}\text { Kişi başına reel gayri safi } \\
\text { yurtiçi hâsıla (y), kişi } \\
\text { başına ilkokula } \\
\text { kayıtlananlar (pri), kişi } \\
\text { başına ortaokula } \\
\text { kayıtlananlar (sec), kişi } \\
\text { başına liseye kayıtlananlar } \\
\text { (high), kişi başına teknik } \\
\text { liselere kayıtlananlar } \\
\text { (thigh), kişi başına yüksek } \\
\text { öğretime kayitlananlar } \\
\text { (uni) }\end{array}$ & $\begin{array}{l}\text { ARDL, Granger } \\
\text { Nedensellik Testi }\end{array}$ & $\begin{array}{c}\text { Uzun dönem } \\
\text { eşbütünleşme ilişkisi } \\
\text { vardır. Uzun } \\
\text { dönemde:y pri, } \\
\text { y } \rightarrow \text { sec,y } \rightarrow \text { thigh,y } \longrightarrow \text { phigh, } \\
\text { Kısa dönemde: } \\
\text { sec } \rightarrow \text { y,high } \rightarrow \text { y, } \\
\text { thigh } \rightarrow \text { y,pri } \rightarrow \text { sec, } \\
\text { high } \rightarrow \text { sec, } \\
\text { high } \rightarrow \text { uni }\end{array}$ \\
\hline $\begin{array}{c}\text { Şimşek ve Kadılar } \\
\text { (2010) }\end{array}$ & 1960-2004 & $\begin{array}{l}\text { Reel gayri safi yurtiçi } \\
\text { hâs1la (GDP), reel ihracat } \\
\text { (EX), yüksek öğrenime } \\
\text { kayıt sayısı (BS) }\end{array}$ & $\begin{array}{c}\text { ARDL, Johansen } \\
\text { Eşbütünleşme Testi, } \\
\text { Granger Nedensellik } \\
\text { Testi }\end{array}$ & $\begin{array}{l}\text { Uzun dönemli ilişki } \\
\text { vardır. Uzun dönemde } \\
\text { EX ve BS'deki artış } \\
\text { GDP'yi arttırmaktadır. } \\
\text { Uzun ve kısa dönemde } \\
\text { (EX ve BS) } \rightarrow \text { GDP; } \\
\text { Kısa dönemde } \\
\text { BS } \rightarrow \text { GDP }\end{array}$ \\
\hline $\begin{array}{c}\text { Telatar ve Terzi } \\
\text { (2010) }\end{array}$ & $1968-2006$ & $\begin{array}{l}\text { Nüfus (N), Kişi başına } \\
\text { gayri safi milli hâsıla } \\
\text { (YKB), meslek lisesinden } \\
\text { mezun olan öğrenci sayıs } \\
\text { (ML), genel liselerden } \\
\text { mezun olan öğrenci sayıs } \\
\text { (GL), yüksek öğretimden } \\
\text { mezun olan öğrenci sayıs } \\
\text { (YÖ) }\end{array}$ & $\begin{array}{c}\text { Granger Nedensellik, } \\
\text { VAR }\end{array}$ & $\begin{array}{l}\text { YKB'den N'ye doğru } \\
\text { negatif, YÖ'ye doğru } \\
\text { pozitif nedensellik } \\
\text { ilişkisi rastlanmışken; } \\
\text { ML'den YKB'ye } \\
\text { pozitif nedensellik } \\
\text { ilişkisi vardır. }\end{array}$ \\
\hline $\begin{array}{c}\text { Karataş ve Çankaya } \\
\qquad(2011)\end{array}$ & $1981-2006$ & $\begin{array}{l}\text { Kişi başına reel gayri safi } \\
\text { yurtiçi hâsıla artış hızı } \\
\text { (GDPPC), sabit sermaye } \\
\text { yatırımlarının gayri safi } \\
\text { yurtiçi hâsılaya oranı } \\
\text { (SSYAH), eğitim } \\
\text { harcamalarının gayri safi } \\
\text { yurtiçi hâsılaya oranı } \\
\text { (EDU), sağlık } \\
\text { harcamalarının gayri safi } \\
\text { yurtiçi hâsılaya oranı } \\
\text { (HEALTH), } \\
\text { yükseköğretim okullaşma } \\
\text { oranı (ENROL) }\end{array}$ & EKK & $\begin{array}{c}\text { Sabit sermaye } \\
\text { yatırımları, eğitim ve } \\
\text { sağlık harcamaları ile } \\
\text { yükseköğretim } \\
\text { okullaşma oranının } \\
\text { ekonomik büyümeye } \\
\text { etkisi pozitif }\end{array}$ \\
\hline Akçacı (2013) & 1998Q1-2012Q3 & $\begin{array}{l}\text { Reel gayri safi yurtiçi } \\
\text { hâsıla (GS), reel eğitim } \\
\text { harcamaları (ES) }\end{array}$ & $\begin{array}{l}\text { Toda-Yamamoto } \\
\text { Nedensellik Testi }\end{array}$ & $\mathrm{ES} \rightarrow \mathrm{GS}$ \\
\hline $\begin{array}{l}\text { Çalışkan vd. } \\
\text { (2013a) }\end{array}$ & $1967-2010$ & $\begin{array}{c}\text { Reel gayri safi yurtiçi } \\
\text { hâsıla (RGDP), doğumda } \\
\text { yaşam beklentisi (LIFE), } \\
\text { hastane sayısı } \\
\text { (HOSPITAL), sağlık } \\
\text { personeli başına düşen kişi } \\
\text { sayısı (PERSONAL), } \\
\text { sağlık kurumlarına ait } \\
\text { yatak sayıları (BED), }\end{array}$ & $\begin{array}{c}\text { Johansen } \\
\text { Eşbütünleşme Testi, } \\
\text { Granger Nedensellik } \\
\text { Testi }\end{array}$ & $\begin{array}{l}\text { Uzun dönem } \\
\text { eşbütünleşme ilişkisi } \\
\text { yoktur. } \\
\text { PERSONAL } \rightarrow \\
\text { RGDP, BED } \rightarrow \text { RGDP, } \\
\text { HOSPITAL } \rightarrow \text { RGDP, } \\
\text { Tüm değişkenler } \rightarrow \\
\text { RGDP }\end{array}$ \\
\hline
\end{tabular}




\begin{tabular}{|c|c|c|c|c|}
\hline $\begin{array}{l}\text { Çalışkan vd. } \\
\text { (2013b) }\end{array}$ & 1923-2011 & $\begin{array}{c}\text { Gayri safi yurtiçi hâsıla } \\
\text { (GSYH), ilkokula kayıtlı } \\
\text { ögrenci sayısı } \\
\text { (PRIMARY), liseye } \\
\text { kayı̈lı ögrenci sayısı } \\
\text { (HSCHOOL), teknik } \\
\text { liseye kayıtlı öğrenci } \\
\text { sayısı (TECH), } \\
\text { yükseköğretime kayıtlı } \\
\text { öğrenci sayısı (HIGHER) }\end{array}$ & $\begin{array}{c}\text { Johansen } \\
\text { Eşbütünleşme Testi }\end{array}$ & $\begin{array}{c}\text { Uzun dönem ilişkisi } \\
\text { vardır. HSCHOOL ve } \\
\text { HIGHER } \\
\text { değişkenlerine ait } \\
\text { katsayılar istatistiki } \\
\text { olarak anlamlı ve } \\
\text { pozitiftir. }\end{array}$ \\
\hline $\begin{array}{l}\text { Özşahin ve Karaçor } \\
\text { (2013) }\end{array}$ & $1980-2010$ & $\begin{array}{l}\text { Gayri safi yurtiçi hâsıla } \\
\text { (Y), toplam işgücü (LF), } \\
\text { işgücüne katılım oranı } \\
\text { (LFPR), eğitim } \\
\text { harcamalarında } \\
\text { yükseköğrenime ayrılan } \\
\text { pay (HEE), } \\
\text { yükseköğrenime } \\
\text { kayıtlananlar (EHE), } \\
\text { istihdam oranı (ER) }\end{array}$ & EKK & $\begin{array}{l}\text { ER'nin Y üzerindeki } \\
\text { etkisi negatifken, HEE } \\
\text { ve EHE'nin Y } \\
\text { üzerindeki etkisi } \\
\text { pozitif. }\end{array}$ \\
\hline $\begin{array}{l}\text { Pamuk ve Bektaş } \\
\text { (2014) }\end{array}$ & 1998:01-2013:02 & $\begin{array}{l}\text { Reel gayri safi yurtiçi } \\
\text { hâsıla (GSYİH), reel } \\
\text { eğitim harcamaları (EG) }\end{array}$ & $\begin{array}{l}\text { ARDL Sinır Testi, } \\
\text { Granger Nedensellik } \\
\text { Testi }\end{array}$ & $\begin{array}{c}\text { Uzun dönem ilişki } \\
\text { yok. } \\
\text { GSYİH } \rightarrow \text { EG }\end{array}$ \\
\hline Ener vd. (2015) & 1980-2013 & $\begin{array}{l}\text { Kişi başına düş̧en gelir } \\
\text { (Y), ihracat oranı (EX), } \\
\text { yüksek öğretim okullaşma } \\
\text { oranı (HC) }\end{array}$ & $\begin{array}{c}\text { Engle-Granger } \\
\text { Eşbütünleşme Testi, } \\
\text { Granger Nedensellik } \\
\text { Testi, }\end{array}$ & $\begin{array}{c}\text { Eşbütünleşme ilişkisi } \\
\text { vardır. } \\
\mathrm{HC} \leftrightarrow \mathrm{Y}, \\
\mathrm{HC} \leftrightarrow \mathrm{EX}, \\
\mathrm{EX}-\mathrm{Y}\end{array}$ \\
\hline Manga vd. $(2015)^{1}$ & $1995-2011$ & $\begin{array}{c}\text { Beşeri sermaye endeksi, } \\
\text { Reel sabit sermaye, reel } \\
\text { gayri safi yurtiçi hâsıla }\end{array}$ & $\begin{array}{c}\text { Pedroni, Kao } \\
\text { Eşbütünleşme Testleri, } \\
\text { Panel FMOLS }\end{array}$ & $\begin{array}{l}\text { Uzun dönemli ilişki } \\
\text { vardır. Beşeri } \\
\text { sermayenin ekonomik } \\
\text { büyüme üzerindeki } \\
\text { etkisi pozitif. }\end{array}$ \\
\hline Şimşir vd. (2015) & $1975-2012$ & $\begin{array}{c}\text { Reel kişi başına gayri safi } \\
\text { yurtiçi hasıla (GRO), } \\
\text { toplam sağlık } \\
\text { harcamalarının gayri safi } \\
\text { yurtiçi hasılaya oranı } \\
\text { (HEA), kaba ölüm oranı } \\
\text { (DR), doktor sayısı (DOC) }\end{array}$ & ARDL & $\begin{array}{c}\text { Uzun dönemde HEA, } \\
\text { DR ve DOC } \\
\text { değişkenlerinin GRO } \\
\text { üzerindeki etkisi } \\
\text { negatifken kısa } \\
\text { dönemde ise cari } \\
\text { dönemdeki HEA ile } \\
\text { GRO arasında negatif } \\
\text { ilişki vardır. }\end{array}$ \\
\hline Topallı (2015) & 1960-2012 & $\begin{array}{l}\text { Kişi başına reel gayri safi } \\
\text { yurtiçi hâsıla (RY), } \\
\text { üniversitelerden (TFA), } \\
\text { mesleki ve teknik } \\
\text { liselerden (TMT) diploma } \\
\text { alanların toplam sayıs1, } \\
\text { toplam doktor sayısı } \\
\text { (TDO) }\end{array}$ & $\begin{array}{c}\text { Johansen } \\
\text { Eşbütünleşme, } \\
\text { Dolado-Lütkepohl } \\
\text { Granger Nedensellik } \\
\text { Testi }\end{array}$ & $\begin{array}{c}\text { Uzun dönemde } \\
\text { eşbütünleşme ilişkisi } \\
\text { vardır. } \\
\text { TMT } \rightarrow \text { RY } \\
\text { TDO } \rightarrow \text { RY } \\
\text { RY } \rightarrow \text { TFA }\end{array}$ \\
\hline
\end{tabular}

\footnotetext{
${ }^{1}$ Söz konusu çalışmada analizler, BRICS ve Türkiye üzerine gerçekleştirilmiştir. Fakat Tablo 1'de yalnızca Türkiye için elde edilen bulgular paylaşılmıştır.
} 


\begin{tabular}{|c|c|c|c|c|}
\hline $\begin{array}{c}\text { Yurtkuran ve Terzi } \\
\text { (2015) }\end{array}$ & $1950-2012$ & $\begin{array}{l}\text { Reel gayri safi milli hasıla } \\
(\mathrm{Y}), \text { meslek lisesini }(\mathrm{V}), \\
\text { genel liseyi }(\mathrm{G}), \\
\text { üniversiteyi (U) } \\
\text { tamamlayan ögrenci sayısı }\end{array}$ & $\begin{array}{c}\text { Standart Granger } \\
\text { Nedensellik, Hsiao } \\
\text { Granger } \\
\text { Nedensellik Testi, } \\
\text { Dolado-Lütkepohl } \\
\text { Granger Nedensellik } \\
\end{array}$ & $\begin{array}{l}\text { Y'den U'ya tek yönlü } \\
\text { pozitif nedensellik, V } \\
\text { ve G'den Y'ye tek } \\
\text { yönlü pozitif } \\
\text { nedensellik }\end{array}$ \\
\hline Başar vd. (2016) & 1998Q1-2016Q1 & $\begin{array}{l}\text { Reel gayri safi yurtiçi } \\
\text { hâsıla (GSYH), reel } \\
\text { eğitim harcamaları (EH), } \\
\text { reel sağlık harcamaları } \\
\text { (SH) }\end{array}$ & $\begin{array}{l}\text { ARDL Sinır Testi ve } \\
\text { Hata Düzeltme Modeli }\end{array}$ & $\begin{array}{l}\text { Uzun dönemde SH, } \\
\text { GSYH üzerinde } \\
\text { pozitif etkisi varken } \\
\text { EH, GSYH üzerinde } \\
\text { anlamlı bir etkisi } \\
\text { yoktur. }\end{array}$ \\
\hline Boztosun vd. (2016) & 1961-2011 & $\begin{array}{l}\text { Reel gayri safi yurtiçi } \\
\text { hâsıla (GDP), beşeri } \\
\text { sermaye endeksi (HC) }\end{array}$ & $\begin{array}{c}\text { Hatemi-J } \\
\text { Eşbütünleşme Testi, } \\
\text { Hacker ve Hatemi-J } \\
\text { Nedensellik Testi, } \\
\text { OLS, DOLS, FMOLS, } \\
\text { CCR }\end{array}$ & $\begin{array}{c}\text { Uzun dönem } \\
\text { eşbütünleşme ilişkisi } \\
\text { ve iki yönlü } \\
\text { nedensellik ilişkisi } \\
\text { vardır. Uzun dönemde } \\
\text { beşeri sermayenin } \\
\text { ekonomik büyüme } \\
\text { üzerinde pozitif etkisi } \\
\text { vardır. } \\
\end{array}$ \\
\hline Gövdeli (2016) & 1923-2014 & $\begin{array}{c}\text { Reel gayri safi yurtiçi } \\
\text { hâs1la (GSYİH), } \\
\text { ilköğretime kayıtlı öğrenci } \\
\text { sayısı (ÏÖ), liseye kayıtlı } \\
\text { öğrenci sayısı (LISE), } \\
\text { meslek lisesine kayıtlı } \\
\text { öğrenci sayıs1 (MLISE), } \\
\text { üniversiteye kayıtlı } \\
\text { öğrenci sayısı (UNV) }\end{array}$ & $\begin{array}{c}\text { Maki Eşbütünleşme } \\
\text { Testi, FMOLS, } \\
\text { Hacker ve Hatemi } \\
\text { Bootstrap Nedensellik } \\
\text { Analizi }\end{array}$ & $\begin{array}{l}\text { Uzun dönemli iliş̧i } \\
\text { vardır. Uzun dönemde } \\
\text { MLISE dişındaki tüm } \\
\text { değişkenler GSYİH'yi } \\
\text { arttırmaktadır. } \\
\text { ÏÖ } \rightarrow \text { GSYİH, } \\
\text { GSYİH } \rightarrow \text { LISE }\end{array}$ \\
\hline $\begin{array}{l}\text { Terzi ve Yurtkuran } \\
\qquad(2016)\end{array}$ & $1950-2012$ & $\begin{array}{c}\text { Gayri safi milli hasıla }(Y), \\
\text { meslek liselerinden }(\mathrm{M}), \\
\text { genel liselerden }(\mathrm{G}), \\
\text { üniversitelerden }(\mathrm{U}) \\
\text { mezun öğrenci sayıs1 } \\
\end{array}$ & $\begin{array}{c}\text { Sims, Toda- } \\
\text { Yamamoto } \\
\text { Nedensellik Testleri }\end{array}$ & $\begin{array}{c}\text { Y'den U'ya pozitif } \\
\text { nedensellik ile M ve } \\
\text { G'den Y'ye pozitif } \\
\text { nedensellik ilişkisine } \\
\text { ulaşılmıştır. } \\
\end{array}$ \\
\hline Durmuş $(2017)^{2}$ & $1999-2013$ & $\begin{array}{c}\text { Gayri safi yurtiçi } \\
\text { hâsıladaki artış oranı } \\
\text { (EB), Eğitim } \\
\text { harcamalarının gayri safi } \\
\text { yurtiçi hâsıladaki payı } \\
\text { (EH) }\end{array}$ & $\begin{array}{l}\text { Westerlund ve } \\
\text { Edgerton Panel } \\
\text { Eşbütünleşme Testi, } \\
\text { Pesaran Ortak İlişkili } \\
\text { Etkiler (CCE) Modeli }\end{array}$ & $\begin{array}{c}\text { Uzun dönem } \\
\text { eşbütünleşme ilişkisi } \\
\text { vardır. Eğitim } \\
\text { harcamaları ekonomik } \\
\text { büyümeye pozitif } \\
\text { yansımaktadır. }\end{array}$ \\
\hline $\begin{array}{l}\text { Köprücü ve Sarıtaş } \\
\text { (2017) }\end{array}$ & $1980-2013$ & $\begin{array}{l}\text { Kişi başına düşen gelir } \\
\text { (Y), sabit sermayenin } \\
\text { milli gelire oranı }(\mathrm{K}), \\
\text { istihdam oranı }(\mathrm{L}), \\
\text { ortaokullaşma oranı } \\
\text { (educ) }\end{array}$ & $\begin{array}{l}\text { ARDL, Johansen } \\
\text { Eşbütünleşme Testi, } \\
\text { Toda-Yamamota } \\
\text { Yaklaşımı }\end{array}$ & $\begin{array}{l}\text { Uzun dönem ilişkisi } \\
\text { vardır. Uzun dönemde } \\
\text { Y, K, L ve educ } \\
\text { parametreleri } \\
\text { pozitiftir. K } \rightarrow \text { Y, } \\
\mathrm{L} \rightarrow \mathrm{Y} \text {, educ } \rightarrow \text { Y, } \\
\text { Tüm değişkenler } \rightarrow \text { Y }\end{array}$ \\
\hline
\end{tabular}

Tablo 1'de görüldüğü üzere literatürdeki ampirik çalışmalarda beşeri sermayeyi temsil etmek üzere birçok farklı değişkenden yararlanılmıştır. Bu yüzden ekonometrik analizlerde kullanılan farklı değişkenler farklı sonuçlar vermiştir. Fakat çoğunlukla beşeri sermaye ve ekonomik büyüme arasında uzun dönemde eşbütünleşme ilişkisine rastlanılmıştır. Teorik literatürde beşeri sermayenin büyüme üzerinde pozitif etkisi vurgulanırken söz konusu etkiyi araştıran ampirik çalışmalarda ise birbirinden farklı bulgulara ulaşılmıştır.

\footnotetext{
${ }^{2}$ Çalışmada eğitim harcamaları ile ekonomik büyüme arasındaki ilişki Türkiye, Azerbaycan, Ermenistan, İran ve Güney Kıbrıs ülkeleri için araştırılmış olup Tablo 1'de sadece Türkiye'ye ilişkin sonuçlar değerlendirilmiştir.
} 


\section{VERİ SETİ, AMPIRIKK MODEL VE YÖNTEM}

Çalışmanın bu kısmında 1978 - 2014 dönemi için Türkiye'de fiziksel ve beşeri sermayenin ekonomik büyüme üzerindeki etkilerini araştırmak için kullanılan model sunulmuştur. Bunun yanında bu bölüm, çalışmada kullanılan veri kaynaklarını, araştırma tekniklerini ve tanımlayıcı testleri de içermektedir.

\subsection{Veri Seti ve Kaynağı}

$\mathrm{Bu}$ çalışma beşeri sermaye ile fiziki sermayenin ekonomik büyüme ile uzun ve kısa dönem ilişkisini ortaya koymaktadır. Bu doğrultuda çalışmadaki tüm analizler ikincil verilere dayandırılarak gerçekleştirilmiştir. Bu çalışmanın analiz kısmı, 1978 - 2014 dönemi boyunca Türkiye için yıllık zaman serisini içermektedir. Fiziki sermayeyi temsilen kullanılan brüt sabit sermaye oluşumunun gayri safi yurtiçi hâsıladaki payı ile ekonomik büyümenin vekil değişkeni; 2010 yılı sabit fiyatlarla kişi başına gayri safi yurtiçi hâsıla verilerine Dünya Bankası'nın veri tabanından ulaşılmışken, beşeri sermaye göstergesi olarak kullanılan beşeri sermaye endeksi ise Penn World Table (v9.0)' dan alınmıştır. Söz konusu endeks, ortalama okullaşma süresine (Barro ve Lee, 2013) ve eğitimin getiri oranına (Psacharopoulos, 1994) dayanmaktadır.

\subsection{Ampirik Model}

Fiziksel ve beşeri sermayenin ekonomik büyüme üzerindeki etkilerini araştırmak üzere kurulan ekonometrik model denklem 2 ve 3 'te gösterilmektedir:

$$
p g d p=f(s g f c, h c)
$$

Denklem 1, ekonometrik formda şu şekilde yazılabilir:

$$
\begin{aligned}
& p g d p_{t}=a+\beta s g f c_{t}+\delta h c_{t}+u_{t} \\
& u_{t}=\text { stokastik terim, } t=1,2,3,4, \ldots, 37(1978-2014 \text { dönemi })
\end{aligned}
$$

Denklem 2'de pgdp, sgfc ve he terimleri sırasıyla kişi başına gayri safi yurtiçi hâsılayı (2010 usd), brüt sabit sermaye oluşumunun gayri safi yurtiçi hâsıladaki payını (\%) ve beşeri sermaye endeksini temsil etmektedir. $a, \beta, \delta$ tahmin edilecek parametrelerdir. pgdp ve hc değişkenlerinin doğal logaritması alınarak oluşturulan yeni ekonometrik model ise tekrardan düzenlenip yazılırsa;

$$
\ln (p g d p)_{t}=a+\beta s g f c_{t}+\delta \ln (h c)_{t}+u_{t}
$$

\subsection{Yöntem: Gecikmesi Dağıtılmış Otoregresif (ARDL) Modeli}

Uzun vadeli ilişkileri ve değişkenler arasındaki dinamik etkileşimleri ampirik olarak analiz etmek için Pesaran vd. (2001) tarafından geliştirilen yaklaşım kullanılarak tahminlerde bulunulmuştur. $\mathrm{Bu}$ yaklaşım Gecikmesi Alınmış Otoregresif (ARDL) olarak adlandırılmakla beraber ARDL sınır testi yaklaşımı olarak da bilinmektedir. Bu yöntemin kullanılmasına üç sebepten ötürü karar verilmiştir. İlk olarak, sınır testinin uygulanması oldukça basit bir süreçten oluşmaktadır. Johansen(1991) ile Johansen ve Juselius(1990)' in geliştirmiş oldukları diğer çok değişkenli eşbütünleşme tekniklerinin aksine, ARDL yöntemi, modelin gecikme değerlerinin belirlenmesinin akabinde eşbütünleşme ilişkisinin OLS tarafından tahmin edilmesine izin vermektedir. İkinci olarak, bu yaklaşım Johansen eşbütünleşme gibi diğer tekniklerin aksine, modelde yer alan değişkenlerin ön teste yani birim kök testlerine tabi tutulmasını gerektirmemektedir. Başka bir ifadeyle ARDL sınır testi yaklaşımı, modeldeki regresörlerin 
tamamının I (0), I (1) veya karşılıklı olarak birlikte entegre edilmiş olup olmadığına bakmaksızın uygulanabilir. Üçüncü olarak, ARDL modeli daha güçlü olup standart eşbütünleşme yöntemlerine kıyasla küçük bir örneklem boyutu için daha iyi bir performans göstermektedir (Pesaran ve Shin, 1999). ARDL'ye göre kısıtlanmamış fonksiyon aşağıda gösterildiği şekilde yazılmıştır:

$v_{t}(4)$

$$
\Delta \operatorname{lnpgdp_{t}}=\theta_{0}+\sum_{i=1}^{n} a_{1 i} \Delta \operatorname{lnpg} d p_{t-i}+\sum_{i=1}^{n} \beta_{1 i} \Delta s g f c_{t-i}+\sum_{i=1}^{n} \delta_{1 i} \Delta \operatorname{lnh} c_{t-i}+
$$

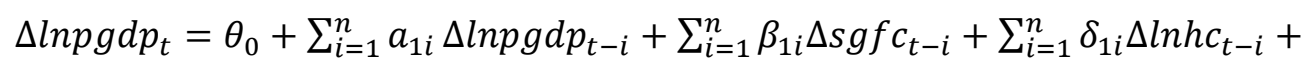

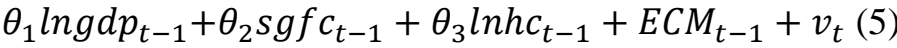

$\mathrm{n}$, maksimum gecikme uzunluğu; $a_{1}, \beta_{1}, \delta_{1}$, k1sa dönem dinamik parametreleri; $\theta_{1}, \theta_{2}, \theta_{3}$ terimleri ise uzun dönem çarpanlarıdır. Değişkenler arasında uzun dönem ilişkisinin olup olmadığ 1 ortak boş hipotezi sınayarak gerçekleştirilebilir: $H_{0}: \theta_{1}=\theta_{2}=\theta_{3}=0$ buna karşın $H_{1}: \theta_{1} \neq \theta_{2} \neq \theta_{3} \neq 0$.

F-testi değişkenler arasında uzun süreli ilişkilerin olup olmadığını test etmek için kullanılır. Buradan hareketle, Pesaran vd. (2001) her bir anlamlılık düzeyi için iki tür kritik değer hesaplar. Biri tüm değişkenlerin $\mathrm{I}(0)$ olduğunu varsayarken diğeri ise $\mathrm{I}(1)$ olduğunu varsayar. Hesaplanan F-istatistik değeri üst sınır kritik değerinin üzerinde olması halinde, $H_{0}$ (boş hipotez) reddedilir. Hesaplanan F-istatistik değeri alt ve üst kritik değerlerin arasında yer alması halinde söz konusu test ile bir sonuç elde edilemeyecek olunup testin sonuçsuz olduğu belirtilecektir. Son olarak eğer hesaplanan F-istatistik değeri alt sınır kritik değerin altında olursa, eşbütünleşmenin olmadığı bulgusuna ulaşılacaktır. F-istatistiği için yaklaşık kritik değerler Pesaran vd. (2001)'den ulaşılmıştır.

Bir diğer adım, ARDL yaklaşımı ile tahminde bulunabilmek üzere gerekli olan optimum gecikme uzunluğunu tespit edebilmektir. ARDL modelinde gecikme düzeylerini tespit etmek için sıklıkla optimum gecikmelere yönelik seçim kriterlerine başvurulur. Bu kriterler, Akaike Bilgi Kriteri (AIC) ve Schwartz Bilgi Kriteri (SIC)'dir. AIC ve SIC kriterleri ile ARDL modeli tahmin edildikten sonra değişkenlerin uzun dönem katsayıları tahmin edilebilir. Uzun dönem katsayı tahmininden sonra çeşitli tanısal testler ve tahmini yapılan modelin kararlı olup olmadığını görebilmek adına kararlılık testleri uygulanır. Bu doğrultuda, çalışmada oto korelasyon, değişen varyans, normallik ile kararlılık testleri kullanılmıştır.

\section{AMPİRİK SONUÇLAR}

\subsection{Birim Kök Test Sonuçları}

ARDL sınır testi yaklaşımı, modeldeki regresörlerin tamamının I(0), I(1) veya karşıllıklı olarak birlikte entegre edilmiş olup olmadığına bakmaksızın uygulanabilmesine karşın sahte regresyon modeli sonuçlarından kaçınmak için modeldeki değişkenlerin ikinci farkında durağan I(2) olmaması gerekmektedir. $\mathrm{Bu}$ yüzden öncelikle serilerin entegrasyon derecelerine bakılmıştır. Ouattara (2004) modeldeki herhangi bir değişkenin entegresyan derecesi birden büyük yani I(2) olursa Pesaran vd. (2001) tarafından sunulan kritik değerlerin geçerli olamayacağını ileri sürmektedir. Çünkü söz konusu kritik değerler değişkenlerin I(0) veya I(1) olmasına dayanarak hesaplanmaktadır. $\mathrm{Bu}$ yüzden modeldeki hiçbir değişkenin I(2) olmadığından emin olabilmek adına ARDL yaklaşımıyla tahminlerde bulunmadan önce birim kök testlerinin uygulanması gerekli görülmektedir.

$\mathrm{Bu}$ amaçla Genişletilmiş Dickey-Fuller (ADF), Phillips-Perron (PP)ve KwiatkowskiPhillips-Schmidt-Shin (KPSS) birim kök testleri uygulanarak değişkenlerin entegrasyon dereceleri tespit edilmiş olup, sonuçlar Tablo 2, Tablo 3 ve Tablo 4 'te gösterilmektedir. 
Tablo 2: ADF Birim Kök Test Sonucu

\begin{tabular}{lcccc}
\hline & \multicolumn{2}{c}{ Sabit } & \multicolumn{2}{c}{ Sabit ve Trend } \\
\hline Değiş̧kenler & $\begin{array}{l}\text { ADF Test } \\
\text { İstatistiği }\end{array}$ & $\begin{array}{c}\text { Entegrasyon } \\
\text { Derecesi }\end{array}$ & $\begin{array}{c}\text { ADF Test } \\
\text { İstatistiği }\end{array}$ & $\begin{array}{c}\text { Entegrasyon } \\
\text { Derecesi }\end{array}$ \\
\hline Inpgdp & -5.931319 & $\mathrm{I}(1)$ & -6.039357 & $\mathrm{I}(1)$ \\
\hline sgfc & -5.536943 & $\mathrm{I}(1)$ & -5.449546 & $\mathrm{I}(1)$ \\
\hline Inhc & -1.844222 & $\mathrm{I}(0)$ veya I(1) değil & -4.656693 & $\mathrm{I}(1)$
\end{tabular}

(a) I(0): Değişken düzeyde durağan; I(1): Değişken birinci farkında durağan.

(b) ADF istatistiği kritik değerleri (sabit) \%1, \%5 ve \%10 sırasıyla $-3.632900,-2.948404,-2.612874$. ADF istatistiği kritik değerleri (sabit ve trend) \%1, \%5, \%10 sirasıyla $-4.243644,-3.544284,-3.204699$.

Tablo 2’de görüldüğü üzere sadece sabitin olduğu durumda ADF birim kök testi, lnpgdp ve sgfc değişkenlerin birinci farkında durağan I(1) olduklarını gösterirken sabit ve trendin dâhil edildiği durumda tüm değişkenlerin I(1) olduğu yani birinci farkları alındıktan sonra durağanlaştı̆ıını ortaya koymaktadır.

Tablo 3: PP Birim Kök Test Sonucu

\begin{tabular}{lcccc}
\hline & \multicolumn{2}{c}{ Sabit } & \multicolumn{2}{c}{ Sabit ve Trend } \\
\hline Değişkenler & PP Test İstatistiği & $\begin{array}{c}\text { Entegrasyon } \\
\text { Derecesi }\end{array}$ & PP Test İstatistiği & $\begin{array}{c}\text { Entegrasyon } \\
\text { Derecesi }\end{array}$ \\
Inpgdp & -5.946955 & $\mathrm{I}(1)$ & -6.074141 & $\mathrm{I}(1)$ \\
sgfc & -5.783575 & $\mathrm{I}(1)$ & -5.667647 & $\mathrm{I}(1)$ \\
Inhc & -1.983043 & $\mathrm{I}(0)$ veya I(1) değil & -2.204329 & $\mathrm{I}(0)$ veya I(1) değil
\end{tabular}

(a) PP istatistiği kritik değerleri (sabit) $\% 1, \% 5$ ve $\% 10$ sirasıyla $-3.632900,-2.948404,-2.612874,-2.612874$. PP istatistiği kritik değerleri (sabit ve trend) \%1, \%5 ve \%10 sirasılyla -4.243644, -3.544284, 3.204699.

Tablo 3'teki PP birim kök testine ait sonuçlar sabit ile sabit ve trendin olduğu her iki durumda da lnpgdp ve sgfc serilerinin birinci farkı alındığında durağanlaştığını göstermektedir. Tablo 4'te KPSS birim kök test sonuçları sunulmaktadır. ADF ve PP birim kök testlerinin aksine KPSS birim kök testinde " $H_{0}$ : Seri durağandır (birim kök içermez)" ş̧eklindedir.

Tablo 4: KPSS Birim Kök Test Sonucu

\begin{tabular}{lcccc}
\hline & \multicolumn{2}{c}{ Sabit } & \multicolumn{2}{c}{ Sabit ve Trend } \\
Değişkenler & KPSS Test & Entegrasyon & KPSS Test & Entegrasyon \\
& İstatistiği & Derecesi & İstatistiği & Derecesi \\
Inpgdp & 0.197075 & $\mathrm{I}(1)$ & 0.052140 & $\mathrm{I}(1)$ \\
sgfc & 0.071453 & $\mathrm{I}(1)$ & 0.094451 & $\mathrm{I}(0)$ \\
lnhc & 0.293437 & $\mathrm{I}(1)$ & 0.138476 & $\mathrm{I}(0)$ \\
\hline
\end{tabular}

(a) KPSS istatistiği kritik değerleri (sabit) \%1 için 0.739000; sabit ve trend durumunda \%1 için 0.216000 . 
Tablo 4'e göre sabit durumunda KPSS birim kök testi değişkenlerin tamamının birinci dereceden entegre, sabit ve trend durumunda lnpgdp hariç diğer tüm değişkenlerin sıfırıncı dereceden entegre olduğunu göstermiştir.

\subsection{Sınır Testi Sonuçları}

Tablo 5, ARDL sınır testi sonuçlarını göstermektedir. Bu sonuçlara göre hesaplanan Fistatistiği değeri (10.38936); \%1, \%5 ve \%10 anlamlık düzeylerinde üst sınır kritik değerlerinin üzerinde olduğu için değişkenler arasında eşbütünleşme ilişkisinin olmadığını söyleyen boş hipotez reddedilmiştir. Sonuç olarak, değişkenler arasında uzun dönem ilişkine rastlanılmıştır. Bunun yanında Breusch-Godfrey Serial Correlation LM testi, White test ile Breusch-PaganGodfrey, Ramsey Reset, Jarque-Bera gibi birtakım tanısal testler uygulanmış ve sonuçlar Tablo 5'te paylaşılmıştır.

\section{Tablo 5: ARDL Sınır Testi Kritik Değerleri (Trendin Olmadığı Kısıtlanmamış Sabit} Model)

\begin{tabular}{lcc}
\hline F-istatistiği Değeri: $10.38936, \mathrm{k}=2$ & & \\
\hline Kritik Değerler & Alt Sınır Değeri & Üst Sınır Değeri \\
\hline $\boldsymbol{\% 1}$ & 5.15 & 6.36 \\
$\mathbf{\% 5}$ & 3.79 & 4.85 \\
$\mathbf{\% 1 0}$ & 3.17 & 4.14 \\
\hline
\end{tabular}

(a) Kritik değerler Pesaran vd. (2001)'den elde edilmiştir. k terimi regresör sayısını gösterir.

Tablo 6'da görüldüğ̈̈ üzere Breusch-Godfrey LM testi tahmin edilen modelde oto korelasyon probleminin olmadığını, White ile Breusch-Pagan-Godfrey testleri değişen varyans probleminin olmadığını, Jarque-Bera testi hataların normal dağıldığını göstermektedir. Ramsey Reset testi olasılık değeri her ne kadar bir miktar düşük çıssa da $\% 1$ ve $\% 5$ anlamlılık düzeyinin üzerinde olduğu için modelin doğru kurulduğu, fonksiyonel biçim hatasının olmadığ 1 kabul edilmiştir. Bununla beraber modelin $R^{2} v e \bar{R}^{2}$ değerleri sırasıyla 0.785422 ve 0.739440 çıkmış olup; $F$ istatistiği değeri (17.08140) ise \%1 önem düzeyinde istatistiksel olarak anlamlı bulunmuştur.

Tablo 6: Tanısal Testlere İlişkin Sonuçlar

\begin{tabular}{lcc}
\hline Tanısal Testler & İstatistik Değeri & Olasılık Değeri \\
\hline Oto Korelasyon Testi: Breusch- & 0.414502 & 0.6650 \\
Godfrey LM & 1.621942 & 0.1781 \\
\hline Değişen Varyans Testi: White & 1.908204 & 0.1145 \\
\hline $\begin{array}{l}\text { Değişen Varyans Testi: Breusch- } \\
\text { Pagan-Godfrey }\end{array}$ & 1.179026 & 0.554597 \\
\hline Normallik Testi: Jarque-Bera & 1.858511 & 0.0740
\end{tabular}

(a) Jarque-Bera normallik testi dışında diğer tüm tanısal testlerdeki istatistik değerleri F-istatistiğini göstermektedir. 
Değişkenler arasında uzun dönem eşbütünleşme ilişkisi tespit edildikten sonra çalışmanın devamında değişkenlere ilişkin uzun ve kısa dönem dinamik parametreler tahmin edilmiştir. Uzun ve kısa dönem parametreler tahmin edilmeden önce tahmin edilecek ARDL modeli için optimum gecikme uzunluğu belirlenir. Optimum gecikme uzunluğunu belirlemek üzere gecikme derecesi seçim kriterlerine başvurulmuş olunup bu doğrultuda $\operatorname{ARDL}(2,1,1)$ modelinin tahmin edilmesine karar verilmiştir. Tahmin edilen ARDL $(2,1,1)$ modeli Tablo 7'de verilmiştir.

Tablo 7: ARDL $(2,1,1)$ Modeli Tahmin Sonuçları

\begin{tabular}{ccccc}
\hline Değişken & Katsayı & Standart Hata & t-istatistiği & Olasılık \\
\hline $\ln p g d p(-1)$ & 0.430525 & 0.130492 & 3.299255 & $0.0026^{*}$ \\
\hline $\ln p g d p(-2)$ & 0.281921 & 0.100805 & 2.796702 & $0.0092^{*}$ \\
\hline $\operatorname{lnhc}$ & 4.372522 & 0.903906 & 4.837361 & $0.0000^{*}$ \\
\hline $\operatorname{lnh}(-1)$ & -3.805502 & 0.840012 & -4.530294 & $0.0001^{*}$ \\
\hline sgfc & 0.016634 & 0.001961 & 8.484202 & $0.0000^{*}$ \\
\hline sgfc(-1) & -0.007841 & 0.002095 & -3.743192 & $0.0008^{*}$ \\
\hline $\mathrm{C}$ & 1.979755 & 0.583845 & 3.390889 & $0.0021^{*}$ \\
\hline $\mathrm{R}^{2}: 0.994552$ & & Düzeltilmiş R $\mathrm{R}^{2}: 0.993384$ & \\
F-istatistiği: $851.8987(0.000000)$ & Durbin-Watson istatistiği: 2.234581 & \\
\hline
\end{tabular}

* işareti \%1 önem düzeyinde istatistiksel olarak anlamlılı̆̆ belirtmektedir.

Uzun dönem modelin ampirik sonuçları Tablo 8'de sunulurken hata düzeltme modeline ait sonuçlar Tablo 9'da verilmektedir.

Tablo 8: ARDL Uzun Dönem Katsayıları Tahmini

\begin{tabular}{ccccc}
\hline Değişken & Katsayı & Standart Hata & t-istatistiği & Olasıllk \\
\hline Inhc & 1.971871 & 0.176948 & 11.143759 & $0.0000^{*}$ \\
\hline sgfc & 0.030577 & 0.007669 & 3.986919 & $0.0004^{*}$ \\
\hline
\end{tabular}

* işareti \%1 önem düzeyinde istatistiksel olarak anlamlılı̆̆ belirtmektedir.

Tablo 8'deki sonuçlar, uzun dönemde beşeri sermaye ve fiziki sermayenin ekonomik büyüme üzerinde pozitif anlamlı bir etkisi olduğunu işaret etmektedir. Elde edilen bulgulara göre beşeri sermaye endeksi ve brüt gayri safi sabit sermaye oluşumunda \%1'lik artış kişi başına gayri safi yurtiçi hâsılada sırasıyla yaklaşık olarak \%1.97 ve \% 0.03 düzeyinde bir artışa yol açmaktadır. Bunun yanında ölçeğe göre artan getiri $(1.97+0.03=2.0)$ söz konusudur. Bu bulgular 1şığında beşeri sermayenin fiziki sermayeye kıyasla büyümede daha büyük bir katkısının olduğu söylenebilir.

Tablo 9: ARDL Kısa Dönem Katsayıları Tahmini

\begin{tabular}{ccccc}
\hline Değişken & Katsayı & Standart Hata & t-istatistiği & Olasılık \\
\hline $\mathrm{D}(\operatorname{lnggdp}(-1))$ & -0.281921 & 0.091049 & -3.096357 & $0.0044^{*}$ \\
\hline $\mathrm{D}(\operatorname{lnhc})$ & 4.372522 & 0.864662 & 5.056912 & $0.0000^{*}$ \\
\hline $\mathrm{D}(\mathrm{sgfc})$ & 0.016634 & 0.001637 & 10.158425 & $0.0000^{*}$ \\
\hline $\mathrm{c}$ & 1.979755 & 0.339664 & 5.828566 & $0.0000^{*}$ \\
\hline $\mathrm{ECT}(-1)$ & -0.287554 & 0.049760 & -5.778787 & $0.0000^{*}$ \\
\hline
\end{tabular}

\footnotetext{
* işareti \%1 önem düzeyinde istatistiksel olarak anlamlılı̆̆ belirtmektedir.
} 
ARDL modeli kullanılarak uzun dönem eşbütünleşme ilişkisi tahmin edildikten sonra son olarak Hata Düzeltme Modeli ile uzun dönem ekonomik büyüme fonksiyonunun kısa dönem dinamikleri tahmin edilmiştir. Sonuçlar Tablo 9'da özetlenmiştir. Hata düzeltme terimi (ECT(1)) 0 ve -1 arasında bir değer olduğu takdirde, $t$ zamanında pgdp'ye düzelme, $t-1$ zamandaki hatanın bir oranıdır. Bu durumda ECT, pgdp'nin dıșsal 'zorlayıcı değișkenlerdeki' değișikliklerle ilişskili olarak uzun dönemde dengeye aşırı dalgalanma olmaksızın kararlı bir şekilde yakınsamasına neden olur (Alam ve Quazi, 2003: 97). Bu durumda Tablo 9 incelendiğinde hata düzeltme parametresi (-0.287554), istatistiksel olarak anlamlı ve 0 ile -1 arasında bir değerdir. Başka bir ifadeyle, uzun dönem dengesine yaklaşmanın aşırı dalgalanma olmadan tekdüze bir şekilde gerçekleşeceği anlamına gelmektedir. Kısa dönemde beşeri sermaye ve fiziki sermayenin ekonomik büyüme ile pozitif ve istatistiksel olarak anlamlı bir ilişkisinin olduğu tespit edilmiştir. Elde edilen bulgular 1şı̆̆ında, kısa dönemde beşeri sermaye ve fiziki sermayenin ekonomik büyümeyi olumlu yönde etkilediği ve aynı zamanda beşeri sermayenin fiziki sermayeye kıyasla daha büyük bir etki yarattığı sonucuna varılmıştır.

Tahmin edilen ARDL modelinin kısa dönem dinamikleri ile birlikte uzun dönem katsayılarının kararlılığı kümülatif hata terimleri toplamı (CUSUM) ve kümülatif hata terimlerinin kareleri toplamı (CUSUMSQ) testleriyle doğrulanmış olup, Şekil 1'de görüldügü üzere CUSUM ve CUSUMSQ eğrisi \%5 anlamlılık düzeyinde kritik değerlerin içerisinde yer aldığı için tüm katsayıların ve hata düzeltme modelinin kararlı olduğu boş hipotezi kabul edilmiştir.
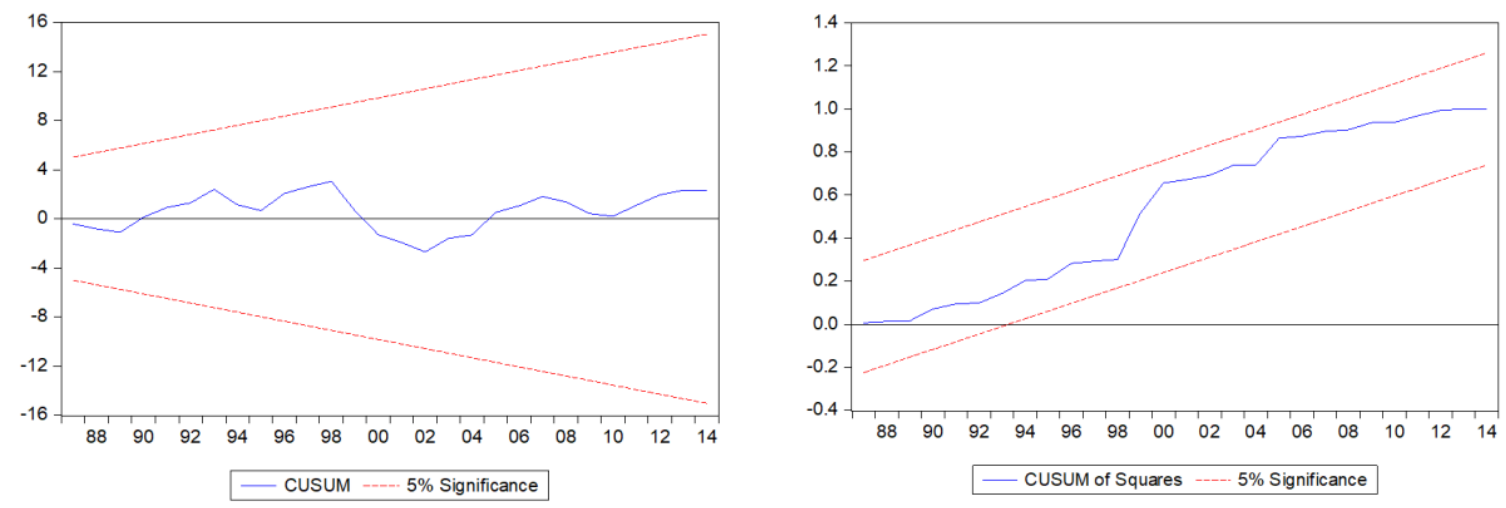

Şekil 1: Kararlılık Testleri: CUSUM ve CUSUMSQ

\section{SONUÇ}

Beşeri sermaye uzun zamandır ekonomik büyüme teorisinin odak noktasında olmuştur. Son zamanlardaki ampirik bulgular, daha yetenekli ve daha eğitimli işgücünün daha yüksek ekonomik büyümenin ön koşullardan biri olduğunu göstermektedir. Bu doğrultuda, bu çalışmada 1978 - 2014 dönemi için Türkiye'de beşeri sermayenin büyüme üzerindeki etkisi araştırılmış ve söz konusu etki ARDL yaklaşımı ile tahmin edilmiştir. Bu bağlamda bağımlı değişkenin kişi başına gayri safi yurtiçi hâsıla, bağımsız değişkenlerin ise brüt sabit sermaye oluşumunun gayri safi yurtiçi hâsıladaki payı ile beşeri sermaye endeksinin olduğu ekonometrik model kurulmuştur. Söz konusu model üzerine uygulanılan sınır testi, değişkenler arasında uzun dönemli bir ilişkinin varlığına işaret etmiştir. Değişkenler arasında uzun dönemli ilişkinin olduğu tespit edildikten sonra kısa ve uzun dönem parametre tahminlerinde bulunulmuştur. Brüt sabit 
sermaye oluşumunun gayri safi yurtiçi hâsıladaki payı ile beşeri sermaye endeksine ait uzun dönem katsayıları sırasıyla 0.03 ve 1.97 olarak bulunmuştur. Bu çalışmada, Manga vd. (2015) ile Boztosun vd. (2016)'ye benzer sonuçlara ulaşlarak uzun dönemde beşeri sermaye ve büyüme arasında eşbütünleşme ilişkisine rastlanılmış olunup beşeri sermayenin fiziki sermayeye kıyasla büyümeye katkısının daha fazla olduğu sonucuna varılmıştır. Bu bağlamda bu çalışma beşeri sermayenin büyüme üzerindeki etkisini ampirik olarak ortaya koymuştur. Bu sonuca göre hükümetler uzun dönemde belli bir çıktı düzeyine ulaşmak istiyorlarsa eğitime daha fazla yatırım yapmak zorundadırlar. Çünkü ancak eğitimli yani yüksek beceri ve bilgi düzeyine sahip insanlarla ülkeler çıktı düzeylerini arttırabilir.

\section{KAYNAKÇA}

Afşar, M. (2009). Türkiye'de eğitim yatırımları ve ekonomik büyüme ilişkisi. Anadolu Üniversitesi Sosyal Bilimler Dergisi, 9, 85 - 98.

Aghion, P., \& Howitt, P. (1992). A model of growth through creative destruction. Econometrica, 60, 323-51.

Akçacı, T. (2013). Eğitim harcamalarının iktisadi büyümeye etkisi. Kafkas Üniversitesi İktisadi ve İdari Bilimler Fakültesi Dergisi, 4(5), 65-79.

Alam, I., \& Quazi, R. (2003). Determinants of capital flight: An econometric case study of Bangladesh. International Review of Applied Economics, 17(1), 85-103.

Altıntaş, H. ve Çetintaş, H. (2010). Türkiye'de ekonomik büyüme, beşeri sermaye ve ihracat arasındaki ilişkilerin ekonometrik analizi: 1970-2005. Erciyes Üniversitesi İktisadi ve İdari Bilimler Fakültesi Dergisi, 36, 33-56.

Arrow, K. J. (1962). The economic implications of learning by doing. The Review of Economic Studies, 29, 155-173.

Barro, R. J. (2001). Human capital and growth. American Economic Review, 91, 12-17.

Barro, R. J., \& Lee, J. W. (2013). A new data set of educational attainment in the world, 1950-2010. Journal of Development Economics, 104, 184-198.

Başar, S., Künü, S., ve Bozma, G. (2016). Eğitim ve sağlık harcamalarının ekonomik büyüme üzerine etkisi: Türkiye üzerine bir uygulama. IIğdır Üniversitesi Sosyal Bilimler Dergisi, 10, 189-204.

Becker, G. S. (1962). Investment in human capital: A theoretical analysis. Journal of Political Economy, 70 (5, Part 2), 9-49.

Beşkaya, A., Savaş, B., \& Şamlığlu, F. (2010). The impact of education on economic growth in Turkey. Süleyman Demirel Üniversitesi İktisadi ve İdari Bilimler Fakültesi Dergisi, 15, 43-62.

Boztosun, D., Aksoylu, S., \& Şentürk Ulucak, Z. (2016). The role of human capital in economic growth. Economics World, 4(3), 101-110.

Çakmak, E. ve Gümüş, S.(2005). Türkiye'de beşeri sermaye ve ekonomik büyüme: ekonometrik bir analiz (1960 2002). Ankara Üniversitesi SBF Dergisi, 60, 59 - 72.

Çalışkan, Ş., Karabacak, M., ve Meçik, O. (2013a). Türkiye'de Sağlık-Ekonomik Büyüme İlişkisi. Dumlupınar Üniversitesi Sosyal Bilimler Dergisi, 37, 123-130.

Çalışkan, Ş., Karabacak, M., ve Meçik, O. (2013b). Türkiye'de eğitim-ekonomik büyüme ilişkisi: 1923-2011 (kantitatif bir yaklaşım). Yönetim Bilimleri Dergisi, 11(21), 29-48.

Çoban, O. (2004). Beşeri sermayenin iktisadi büyüme üzerine etkisi: Türkiye örneği. İstanbul Üniversitesi Siyasal Bilgiler Fakültesi Dergisi, 30, 131-142.

Dakhli, M., \& De Clercq, D. (2004). Human capital, social capital, and innovation: a multi-country study. Entrepreneurship \& Regional Development, 16, 107-128.

Durmuş, S. (2017). Eğitim harcamalarının ekonomik büyüme üzerine etkisi: ampirik bir çalışma. Finans Politik \& Ekonomik Yorumlar, 54(629), 9-18.

Ener, M., Karanfil, M., ve Yıldırım, E. (2015). Ekonomik büyüme, beşeri sermaye ve ihracat arasındaki ilişki: Türkiye Örneği. Girisimcilik ve Kalkinma Dergisi, 10(2), 70 - 85. 
Erdoğan, S. ve Yıldırım, D. Ç. (2009). Türkiye'de eğitim-iktisadi büyüme ilişkisi üzerine ekonometrik bir inceleme. Bilgi Ekonomisi ve Yönetimi Dergisi, 4, 11-22.

Fisher, I. (1906). The nature of capital and income. New York: The Macmillan Company.

Freire Serén, M. J. (2001). Human capital accumulation and economic growth. Investigaciones Economicas, 25, 585602 .

Gövdeli, T. (2016). Türkiye'de eğitim-ekonomik büyüme ilişkisi: yapısal kırılmalı birim kök ve eşbütünleşme analizi. Ömer Halisdemir Üniversitesi İktisadi ve İdari Bilimler Fakültesi Dergisi, 9(3), 223-238.

Johansen, S., \& Juselius, K. (1990). Maximum likelihood estimation and inference on cointegration-with applications to the demand for money. Oxford Bulletin of Economics and Statistics, 52(2), 169-210.

Johansen, S. (1991). Estimation and hypothesis testing of cointegration vectors in Gaussian vector autoregressive models. Econometrica, 59, 1551-1580.

Karataş, M., ve Çankaya, E. (2011). Türkiye'de beşeri sermaye ve ekonomik büyüme ilişkisinin analizi. Journal of Management \& Economics, 18(1), 105-124

Köprücü, Y., ve Sarıtaş, T. (2017). Türkiye'de eğitim ve ekonomik Büyüme: eşbütünleşme yaklaşımı. Optimum Ekonomi ve Yönetim Bilimleri Dergisi, 4(2), 77-89.

Lucas Jr, R. E. (1988). On the mechanics of economic development. Journal of Monetary Economics, 22, 3-42.

Manga, M., Bal, H., Algan, N., ve Kandır, E. D. (2015). Beşeri sermaye, fiziksel sermaye ve ekonomik büyüme ilişkisi: BRICS ülkeleri ve Türkiye örneği. Çukurova Üniversitesi Sosyal Bilimler Enstitüsü Dergisi, 24(1), 45-60.

Mankiw, N. G., Romer, D., \& Weil, D. N. (1992). A contribution to the empirics of economic growth. The Quarterly Journal of Economics, 107, 407-437.

Marshall, A. (1930). Principles of economics. London: Macmillah \& Co.

Mincer, J. (1958). Investment in human capital and personal income distribution. Journal of Political Economy, 66, 281-302.

Ouattara, B. (2004). The Impact of Project Aid and Programme Aid Inflows on Domestic Savings: a Case Study of Côte d'Ivoire. [Available online at: http://citeseerx.ist.psu.edu/viewdoc/download?doi=10.1.1.580.2489\&rep=rep1\&type=pdf], Retrieved on June 7, 2018.

Özsoy, C. (2009). Türkiye'de eğitim ve iktisadi büyüme arasındaki ilişkinin VAR modeli ile analizi. The Journal of Knowledge Economy \& Knowledge Management, 4, 71-83.

Özşahin, Ş., ve Karaçor, Z. (2013). Ekonomik büyümenin belirleyicilerinden biri olarak beşeri sermaye: Yükseköğrenimin Türkiye ekonomisi için önemi. Ömer Halisdemir Üniversitesi İktisadi ve İdari Bilimler Fakültesi Dergisi, 6(1), 148-162.

Pamuk, M., ve Bektaş, H. (2014). Türkiye'de eğitim harcamaları ve ekonomik büyüme arasındaki ilişki: ARDL sınır testi yaklaşımı. Siyaset, Ekonomi ve Yönetim Araştırmaları Dergisi, 2(2), 77-90.

Pesaran, M., \& Shin, Y. (1999). An Autoregressive Distributed-Lag Modelling Approach to Cointegration Analysis. In S. Strøm (Ed.), Econometrics and Economic Theory in the 20th Century: The Ragnar Frisch Centennial Symposium (Econometric Society Monographs, pp. 371-413). Cambridge: Cambridge University Press. doi:10.1017/CCOL521633230.011

Pesaran, M. H., Shin, Y., \& Smith, R. J. (2001). Bounds testing approaches to the analysis of level relationships. Journal of Applied Econometrics, 16(3), 289-326.

Psacharopoulos, G. (1994). Returns to investment in education: A global update. World Development, 22, 1325-1343.

Romer, P. M. (1986). Increasing returns and long-run growth. Journal of Political Economy, 94, 1002-1037.

Romer, P. M. (1990). Endogenous technological change. Journal of Political Economy, 98(5, Part 2), 71 - 102.

Serel, H., \& Masatç1, K. (2005). Türkiye'de beşeri sermaye ve iktisadi büyüme ilişkisi: Ko-entegrasyon analizi. Atatürk Üniversitesi Íktisadi ve İdari Bilimler Dergisi, 19, 49 - 58.

Smith, A. (1776). An inquiry into the nature and causes ofthe wealth ofnations. London: George Routledge and Sons.

Schultz, T. W. (1961). Investment in human capital. The American Economic Review, 51, 1-17.

Şimşek, M., ve Kadılar, C. (2010). Türkiye'de beşeri sermaye, ihracat ve ekonomik büyüme arasındaki ilişkinin nedensellik analizi. CÜ İktisadi ve İdari Bilimler Dergisi, 11, 115-140. 
Şimşir, N. C., Çondur, F., Bölükbaş, M., ve Alataş, S. (2015). Türkiye'de sağlık ve ekonomik büyüme ilişkisi: ARDL sınır testi yaklaşımı. Finans Politik \& Ekonomik Yorumlar Dergisi, 52(604), 43-54.

Telatar, O. M., ve Terzi, H. (2010). Nüfus ve eğitimin ekonomik büyümeye etkisi: Türkiye üzerine bir inceleme. Atatürk Üniversitesi İktisadi ve İdari Bilimler Dergisi, 24(2), 197-214.

Terzi, H., ve Yurtkuran, S. (2016). Türkiye'de eğitim ve iktisadi büyüme ilişkisi: sims ve toda-yamamoto nedensellik analizleri. Eskişsehir Osmangazi Üniversitesi İIBF Dergisi, 11(2), 7-24.

Topallı, N. (2015). Türkiye'de beşeri sermaye ve büyüme ilişkisinin ekonometrik bir analizi. Uludă̆ Üniversitesi Iktisadi ve İdari Bilimler Fakültesi Dergisi, 34(1), 217-234

Weil, D. N. (2009). Economic growth. London: Addison Wesley.

Yurtkuran, S., \& Terzi, H. (2015). Does Education Affect Economic Growth in Turkey? A Causality Analysis. Dokuz Eylül Üniversitesi İktisadi ve İdari Bilimler Fakültesi Dergisi, 30(2), 19-38.

Zortuk, M., Bakırtaş, İ. \& Varsak, S. (2009). The relationship between economic growth and human capital: an empirical analysis for Turkey. Proceedings of the International Symposium on Sustainable Development, 439 - 445. 